\title{
Reading The Tea Leaves: Medvedev's Presidency Through Political Rhetoric Of Federal And Sub-National Actors
}

\author{
Alexander Baturo \\ Dublin City University
}

Slava Mikhaylov

University College London

\begin{abstract}
In the absence of public information on the inner workings of the Russian political regime, especially during Medvedev's presidency, outside observers often have to rely on politicians' unguarded comments or subjective analysis. Instead, we turn to quantitative text analysis of political rhetoric. Treating governors as a quasi-expert panel, we argue that policy positions revealed in regional legislative addresses explain how elites perceived the distribution of power between Putin and Medvedev. We find that governors moved from a neutral position in 2009 to a clearly pro-Putin position in 2011, and that policy initiatives advocated by Medvedev all but evaporated from the rhetoric of governors in 2012.
\end{abstract}

Key Words: Political rhetoric, elite politics, policy point estimation, Russian politics 


\section{INTRODUCTION}

Recent advances in comparative politics underline the crucial importance of institutions that manage intra-elite cooperation to ensure the stability of non- and partly-democratic regimes (e.g., Gandhi 2008; Magaloni 2008). Central to this research agenda is the analysis of the relationship between rulers and their coalitions. Indeed, rulers most often lose office when challenged from within their own ranks (Bueno de Mesquita, Smith, Siverson \& Morrow 2003). When ruling coalitions experience elite defections, regimes can break down (Reuter \& Gandhi 2011). It is often difficult to gauge the extent of centrifugal tendencies, to identify factions, policy differences, and how political elites co-ordinate and choose with whom to side (Lewis 1978). In the past, empirical political science has largely shied away from examining elite politics in less democratic regimes due to highly opaque decision-making structures and the lack of data. Such cases, however, give ample opportunities for speculation amongst pundits, country specialists and historians. For instance, numerous studies of elite politics in the Soviet Union --- often referred to collectively as kremlinology, --- had to infer policy and political changes from the slight variations in physical proximity of country leaders during parades. ${ }^{1}$

Two decades after the demise of the Soviet Union public scrutiny of many aspects of Russian politics is yet again very difficult, resulting in the renewed popularity of the older methods. Indeed, one can argue that kremlinology was back in fashion with the advent of the so-called tandemology --analysis of Dmitry Medvedev's presidency and his relative influence in comparison with his partner in the governing tandem, Prime Minister Vladimir Putin (e.g., Jego 2011). Given the opaque and largely secretive distribution of authority between Medvedev and his prime minister in 2008-12, there were few tools available for empirically oriented scholars interested in the analysis of the president's influence over policy and political elites.

Fortunately, even though the subject of this paper resonates with the earlier scholarship of politics in the Kremlin, the methods for studying latent political processes have recently made

\footnotetext{
${ }^{1}$ See, for example, Ryavec (1982, p. 119): “Chernenko, five years younger, seems closer to Brezhnev and is probably making the most of his control of the General Department and the recent broadening of his activities. At Suslov's funeral in January 1982 he was right next to Brezhnev, a row ahead of Kirilenko."
} 
significant advances. We propose to assess the latent processes of political competition through computerised text analysis (Laver, Benoit \& Garry 2003; Slapin \& Proksch 2008). Focusing on the rhetoric of key national political actors we show that Putin and Medvedev can be clearly differentiated on key policy dimensions. More importantly, the analysis of changes in the rhetoric of regional leaders ('governors') describes the distribution of power between the president and prime minister in 20082012. Based on the original data of 233 annual gubernatorial addresses to regional legislatures, we estimate positions of regional leaders relative to Putin and Medvedev, and trace the evolution of their relative positions over time. We show that governors moved from a neutral position between the two leaders in 2009 to a more clearly pro-Putin position in 2011. We treat governors as a quasi-expert panel, and show how the 'wisdom of crowds' (Surowiecki 2004) can be harvested to map the changes in relative influence of the two leaders. Results obtained from the analysis of rhetoric are validated with the external data from the expert surveys that reveal similar trends in influence over time.

The paper proceeds as follows. Firstly we discuss the validity of Medvedev's presidency and his political rhetoric, and place the case in comparative perspective. Following that, we explain how political alignment can be estimated through quantitative analysis of political rhetoric, and provide evidence for Medvedev's differentiation from Putin on key policy dimensions. Next we demonstrate how changes in the rhetoric of regional governors reflect elite perceptions of Medvedev's presidency over time. Final section concludes and discusses the implication of our results for the study of Russian politics.

\section{MEDVEDEV AS THE `ROLE OCCUPANCY’ LEADER}

In 2008 Vladimir Putin stepped down as the president of Russia after fulfilling his second consecutive term in office. He promoted his protégé Dmitry Medvedev to take over the presidency, in turn accepting the constitutionally second ranking job of prime minister. Upon assuming the presidency, Medvedev moved into a leadership position by virtue of assuming the role of the president with all the prerogatives of the office. In the literature this is known as the 'role occupancy' conceptualisation of leadership (e.g., Northouse, 2009), whereby incumbents lead "not by addressing a crowd ab initio but rather by occupying an office" (Ahlquist \& Levi 2011, p. 19). Between 7 May 2008 and 24 September 2011 the regime was characterised by the duality of executive power shared by 
Prime Minister Putin and President Medvedev in the so-called tandem (Kolesnikov 2008; Sakwa 2010; Rahr 2008).

President Medvedev occupied the top political post in the country with vast constitutional powers vested in his office. Indeed, inter alia, the president is in charge of foreign and security policy and has the power to dismiss the cabinet and dissolve parliament. Premier Putin in his role oversaw matters of socio-economic development, particularly in the aftermath of the 2008 financial crisis. However, Putin also headed the ruling party, United Russia (UR), which cemented elite cohesion (Hale 2010; Remington \& Reuter 2009) and enjoyed a constitutional majority in the lower chamber of parliament. Also, Article 81 (3) of the constitution bans presidential candidates from being re-elected for a third term consecutively, thus leaving room for the Prime Minister to return to his old role in 2012. A significant number of the most influential officials owed their posts personally to Vladimir Putin. These included top officials of the presidential administration, the cabinet, state-owned enterprises, and after 2005 also heads of subnational units. Dmitry Medvedev himself owed his political career to Putin. Hale (2005) describes this situation as 'patronal presidentialism', with Putin being the ultimate arbiter over various elite factions. ${ }^{2}$ Reminiscent of Brezhnev's 'authority building' policy (Breslauer 1982) that promoted the 'stability of cadres' after Khrushchev's policies threatened elite welfare, during his tenure as president Putin rewarded loyalty and largely avoided dismissals in return for the support of elites in maintaining the status quo.

The duality of the federal executive was further exacerbated by the uncertainty over succession. Indeed, unclear distribution of authority between Medvedev and Putin and indeterminacy of the candidacy nomination for the 2012 elections, led to increased uncertainty of the political elites as events unfolded in early 2011. In the words of the Moscow Carnegie Center scholar Nikolai Petrov in the spring of 2011: 'There is serious conflict between certain institutions in Russia that indicates that there is both uncertainty and some kind of struggle' (Samarina 2011). Both Putin and Medvedev continually avoided the succession question, thus leaving ample room for speculation. Formally, this uncertainty existed right until Putin's candidacy announcement at the $U R$ congress on 24 September 2011. Many observers viewed Medvedev as a placeholder for Putin's return to the presidency after one

\footnotetext{
${ }^{2}$ Scholars identify several factions in contemporary Russian politics, including economic liberals and technocrats mainly from St Petersburg, with which Medvedev was thought to be affiliated (Sakwa
} 2010, pp. 125-127). 
obligatory cool-down term (Shevtsova \& Kramer 2012). At the same time, there is considerable evidence that the president advocated his own candidacy behind closed doors and final decision was not revealed to the closest supporters of either leader until the very end. ${ }^{3}$ Subsequent reconstruction in the authoritative daily Vedomosti suggests that as late as the end of August 2011 the political elite still did not know who would be nominated (Kostenko, Taratuta \& Glinkin 2011). The same paper refers to several interlocutors who argued that Medvedev's presidential ambitions might have been thwarted when Putin unexpectedly declared the launch of his own political platform --- All-Russia People's Front --- right before the president's press-conference in May 2011 where Medvedev could have announced his candidacy. Both leaders continued to air opposing views until August when, the daily's sources believe, they both agreed on Putin's candidacy.

\section{Two Modernisations: Political Rhetoric Of President And Prime Minister}

In his influential treatise on the American presidency, Presidential Power, Neustadt (1990) recognised persuasion -- the rhetorical power -- as one of the most important presidential powers setting the public agenda. Presidents can increase the salience of issues by publicising them through the powers of office (Canes-Wrone 2001) and increase popular support for their policy proposals (e.g., Bailey, Sigelman \& Wilcox 2003; Tulis 1987). For instance, Cohen (1995) finds that more attention to

\footnotetext{
${ }^{3}$ Upon hearing that Putin was to return to the presidency and Medvedev was to head the cabinet, Finance Minister Kudrin immediately declared that he did not intend to work in the new cabinet, triggering a prompt dismissal from that post by the angered president, while Medvedev's closest advisor, Dvorkovich, publicly expressed his disappointment and had to be reprimanded. One of the journalists present at the $U R$ congress recalled that Medvedev's name was added and written in by hand to the blank space at the top of the party list only on the day of the convention itself (Orlov 2011, p. 3). In a later interview, Kudrin underlined that the decision announced on 24 September 2011 came as a complete surprise to him on the day, and that he never felt that Medvedev was a mere placeholder [in Russian: 'pritvornyj prezident']. He recalled the cabinet meetings with the president: 'I saw that he wanted to be nominated again. He [Medvedev] underlined it, as a matter of fact, at every meeting. I did not think he pretended.' See Kommersant, January 22, 2012, 'Interview with Alexey Kudrin.' Retrieved 23 January 2012 from http://www.kommersant.ru/doc/1856438.
} 
specific policy issues in presidential State of the Union addresses increases public concern about them, especially those relating to foreign policy. Major speeches can also improve leaders' popularity (Brace \& Hinckley 1992; Ragsdale 1987); the tone of presidential speeches can even alter consumer sentiments and, in turn, indirectly influence the economy (Wood, Owen \& Durham 2005). Other scholars, however, dispute the effects of rhetorical presidency (Edwards 2003, 1996). Thus, Edwards (2003, p. 74) does not find that presidential speeches make any impact on public opinion even though 'they may endow the views of their supporters with structure and purpose.' There are also studies that examine the effects of presidential rhetoric on elite behaviour (Canes-Wrone 2001; Whitfold \& Yates 2003). For instance, Whitfold \& Yates (2003) find that US state attorneys react to the president's rhetorical policy signals by altering the composition of their caseload in reaction to the content of presidential statements. Political rhetoric equally matters in authoritarian regimes and can indicate the existence of factions and future policy direction (Lowenthal 1974). In these settings, the analyses of political rhetoric provides a look at how elite factions with different views compete over policies and future direction (Sakwa 2010, p. 92).

As argued earlier, President Medvedev lacked an independent power base as the majority of the top officials had been previously appointed by Putin. However, in his role as president, Medvedev could uniquely set national political agenda and emphasise or de-emphasise particular issues. As argued by Riker (1986, p. x), leaders often practice heresthetic, the art of political manipulation, where they can, for instance through agenda control, make more prominent a particular issue or a policy dimension that is favourable to them. The opposing leader will have an incentive to attract followers by emphasising or de-emphasising another issue. Whether by design or not, during his brief tenure Medvedev consistently advocated for political liberalisation. Following his departure, Medvedev was criticised for his inability to act on his rhetoric of 'freedom that is better than non-freedom' (e.g., Shevtsova \& Kramer 2012). However, as we demonstrate below, his political rhetoric was not inconsequential and clearly affected political rhetoric within Russian political elites. Arguably, because the office of the president is focal in Russian politics, Medvedev's liberal rhetoric that was prominently broadcast to the elite and public at large for more than three years, even though it was not acted upon, contributed to a wider acceptance of democratic values. It perhaps even exposed the gap between words and deeds, and de-legitimised the regime during the 2011 legislative elections.

During his tenure as president in 2000-08, Putin emphasised the importance of a strong state, 
state-led development, sovereignty, energy security and political stability. This rhetorical emphasis continued during his time in prime-ministerial office. He also spoke on the issue of modernisation, primarily emphasising a state-driven technological modernisation of the economy. In turn, President Medvedev started off emphasising policy continuity with his predecessor: 'we managed to re-assemble the country back together, to stop centrifugal tendencies' (Medvedev 2009). Over time, Medvedev started to position himself as an advocate of more liberal views, both in terms of a liberal economic policy and political liberalisation. He repeatedly argued that an earlier quest for stability and resourceled development at the expense of modernisation and democracy was a dead end. On 10 September 2009 he published a widely discussed policy paper entitled 'Russia, Forward!' (Medvedev 2009). Emphasising that only economic and societal modernisation could liberate Russia from the centuriesold 'curses' of economic underdevelopment, corruption and widespread paternalistic values --- `should we carry with us, into our future, this primitive resource economy, chronic corruption, archaic customs to rely on the state to solve all our problems...' --- Medvedev argued that economic and political modernisation would feed into each other in a virtuous circle:

[The] [P]olitical system in Russia also will be very open, flexible and complex. It will be adequate to the dynamic, mobile, transparent and multifaceted social structure. It will correspond to political culture of free, prosperous, critically thinking, confident people... Parties and coalitions will make federal and regional governments (and not the other way around), nominate the candidates for the head of state office, heads of regions and local selfgovernment.

In 2010 and 2011, his emphasis on societal and political modernisation only increased. In his main media initiative of 2011 -- at a press conference on 18 May 2011, Medvedev underlined that his policy position differed from Putin's in that the latter believed that modernisation was `slow, gradual development', while the president believed that modernisation could be achieved much quicker. ${ }^{4}$ The president's emphasis on the necessity for political and societal modernization rendered his proposed policies appear distinct from Putin's; his elevated position permitted Medvedev to broadcast this

\footnotetext{
${ }^{4}$ Press conference of the President of Russia, 18 May 2011, available at http://kremlin.ru/news/11259, accessed 15 June 2011.
} 
distinctiveness to the domestic audience and particularly to the elites. The president never articulated his position fully and instead chose to allude to his policy differences in numerous speeches and texts. However, the distinctiveness of his policy programme was recognized by external observers. Thus, Gessen (2012, p. 264) notes that two leaders clearly sent different messages in their public addresses, with the president emphasizing more liberal values. Likewise, Mark Urnov $(2011$, p. 2) differentiates between Putin and Medvedev's policies as conservative and liberal programmes of modernisation, respectively, and proposes that

First, the statements of Putin and Medvedev are not just an expression of their personal positions. Of course, the personal positions of the two first figures in the state are important. But it is much more important that their statements reflect the positions of different groups of the Russian elite and the different and competing groups of interest oriented on these two leaders. Second, the dissimilarities in positions of Putin and Medvedev as well as the dissimilarities in positions of "their" groups are not confined to the attitudes to Khodorkovsky and liberal opposition. These dissimilarities mirror a deep divergence in their approaches to the development strategies of the country. So the above-mentioned statements can be regarded as indicators of different political ideologies.

\section{Medvedev's Presidency In Comparative Context}

The situation where President Medvedev could be regarded as neither a figurehead nor a fullyfledged successor, in addition to the secondary evidence we discussed earlier, is further validated by the fact that such leadership is not unique in comparative setting. ${ }^{5}$ In many regimes successors are often appointed as mere placeholders and replaced at the end of the designated terms in office. At the

\footnotetext{
${ }^{5}$ Examples of uncertainty over executive authority at the top abound: for instance, the rivalry between the newly appointed party's general secretary Najibullah and the Chairman of the Revolutionary Council Karmal in Afghanistan in 1985-86, the intermittent jousting over policy between general secretary Brezhnev and his Premier Kosygin in the Soviet Union (Breslau 1982), or the uncertainty over overall influence between general secretary and Premier Hua Guofeng on the one hand and the ascendant vice premier Deng Xiaoping, on the other, in late 1970s in China.
} 
same time, there are also examples where under similar circumstances, de facto leaders often chose to retire and empower their successors. ${ }^{6}$

The practice of shared rulership to ensure smooth succession has a long history. Under diarchy (rule of two) or even tetrarchy (the rule of four) in Roman and Byzantine empires, the senior ruler, Augustus, was to appoint a designated successor as junior emperor, Caesar, and to continue joint rulership until the death or voluntary departure of the former (Gibbon 1998 [1776-88], 206, 227). Similarly, in contemporary China the departing leader and his successor can occupy important posts simultaneously for a certain period of time. ${ }^{7}$ When Jiang Zemin decided to step down, he first vacated the post of the General Secretary of the Central Committee in November 2002, then the Presidency of the Republic in March 2003, and finally the Chairmanship of the Central Military Commission in September 2004. The succession took almost two years. His successor, Hu Jintao stepped into these three posts incrementally after his predecessor vacated them (Duchatel \& Godement 2009).

At the same time, for international or domestic reasons, many leaders relinquish the highest political office temporarily only to return to it later. Indeed, national political leaders do not necessarily occupy the most constitutionally powerful position, a policy called politique de doublure ("politics of understudy") in Haiti (Chehabi \& Linz 1998, p. 17). We calculate from Cheibub, Gandhi \& Vreeland's (2010) data on the nominal and effective leaders that over a hundred of national effective political leaders, or seven per cent of all leaders in 1946-2008 period, controlled their regimes from a different political post or even had no formal position at all. For example, when Serbia's Milošević faced the expiration of his final term in office in 1997, he stood for the presidency of Yugoslavia instead. With him, political power shifted from the Serbian presidency, then assumed by the interim president, Dragan Tomić, and later by Milan Milutinović --- both loyal lieutenants --- to the federal presidency (Lukic 2005, pp. 60-61). Placing the figurehead president can be even more direct. For example, Somoza (Anastasio Garcia) of Nicaragua (1936-56) in 1947, bowing to US pressure, formally stepped down and instead installed a figurehead, President Argüello, who turned on his master, attempted to rule unaided and was ousted only 26 days after inauguration (Lentz 1994, p. 589; Walter 1993). Somoza then placed another figurehead who proved more compliant, yet in 1950 he decided to formally return to office as president. While the majority of nominal (or figurehead) leaders remain

\footnotetext{
${ }^{6}$ Baturo (forthcoming) explains in detail how presidents remain in power beyond binding term limits.
} 
only that -- nominal, twenty of such leaders later emerge to become effective rulers in their own right. ${ }^{8}$

Overall, the comparative evidence suggests that it is not always evident whether the incumbent president is a mere figurehead or simply weaker than his more senior colleague, and whether the latter intends to return to the presidency or engineer the succession and transfer of power. With the benefit of hindsight, Medvedev's presidency is neither the 'understudy' case nor an extended succession, but rather resembles a weak diarchy where the senior ruler decides to return. It strongly resembles the duality of power in Mexico in the 1920-30s when the power was intermittently shared between the president and the head of the ruling party, jefe maximo (Weldon 1997, pp. 248-50).

\section{QUANTITATIVE ANALYSIS OF POLITICAL RHETORIC}

In order to quantitatively examine political rhetoric we treat text as data. Several statistical methods have been developed and successfully applied to the analysis of political competition in developed democracies. The two most widely used methods are Wordscore (Laver, Benoit \& Garry 2003) and Wordfish (Slapin \& Proksch 2008). Both methods assume that the text can be viewed as a 'bag of words' and apply specific statistical algorithms to extract latent policy positions of political actors from their frequency of word usage. The primary difference between the two methods is that Wordscore deductively estimates policy positions on a predefined dimension of political contestation, while Wordfish works more inductively and estimates policy positions of actors on a dimension that has to be subsequently identified (for a recent review see Grimmer and Stewart, forthcoming). ${ }^{9}$

Wordscore employs two documents with already recognized positions as reference texts. In turn, all other documents' positions are then estimated by comparing the latter to the reference texts.

\footnotetext{
${ }^{8}$ Calculations from data in Cheibub, Gandhi \& Vreeland (2010). For example, Balaguer of Dominican republic who served as a figurehead president in 1960-62, after the demise of his former master Trujillo proved to be as effective and rivalled the latter in longevity, serving as president in 1966-78 and 1986-96.

${ }^{9}$ Both methods are implemented in R (Lowe 2011). Additionally Wordscore is also implemented in Stata. However, in order to correctly work with Cyrillic fonts, Stata implementation of Wordscore requires a Russian language version of the operating system.
} 
The choice of reference documents determines the underlying dimension of analysis. Thus, using documents with two opposing views on liberalism would scale those on the underlying dimension of 'civil liberties'. Wordscore has been shown to be equivalent to the Naïve Bayes classifier in the machine learning literature (Benoit and Nulty 2013). Wordscore has been previously applied in the Russian language context in Baturo \& Mikhaylov (2007) to derive policy positions of Russian and Belarusian presidents.

Wordfish does not require reference texts, but as a consequence it doesn't have an a priori definition of the analysed dimension. Wordfish proceeds by taking the same initial information as Wordscore --- frequency of word usage by all actors. Next, assuming that word frequencies are generated by a Poisson distribution the algorithm estimates latent positions of actors on a dimension by applying a variation of the ideal point estimation (Lowe 2008).

Here we employ both methods for substantive and methodological reasons. Thus, our mapping of the alignment of top Russian federal politicians that we undertake in the next section is more suitable for Wordfish, since we do not have clear a priori beliefs on the dimensional structure of political space and specific interpretation of the dimensions will be inferred a posteriori. Substantively, the analysis of relative influence of Medvedev vs. Putin that we undertake following that however lands itself to the application of Wordscore, since we know a priori the dimension of interest (relative influence of two leaders as perceived by regional elites) and we have two clearly identifiable anchors (reference texts) --- addresses by Putin and Medvedev. Methodologically, since Wordscore compares word frequency in virgin texts to the frequency of usage of the same words in reference texts, any region- or governor-specific words that do not appear in reference texts will not influence the analysis. In contrast, Wordfish aims to discriminate actors by relying on their word usage profiles, and thus words used to describe region specific problems will affect the analysis. At the same time, when actors populate the same political space and their texts are assumed to cover the same lexical universe, we can utilise Wordfish to uncover the positioning of top political leaders on the dimensions of political competition.

\section{ANALYSES OF POLICY DIFFERENCES OF FEDERAL POLITICIANS}


In order to map the alignment of top political leaders we require comparable texts produced by comparable actors. We collected political speeches made in similar 'pre-electoral' format prior to the 2011 legislative election at the equivalent of party conventions. The speeches cover all aspects of economic, social, foreign and other policy areas, and are broadly similar to party election manifestos. Our sample includes speeches made by the following politicians: Zyuganov of $K P R F$, Mironov of $S R$, Prokhorov of Pravoe Delo (Just Cause) and Yavlinsky of Yabloko. Likewise, we add Vladimir Putin's speech at the United Russia convention (27 November 2011). ${ }^{10}$ President Medvedev did not make major policy speeches at party conventions late in 2011. However, we used his speech made at the extended press conference on 18 May 2011, which is widely considered to be his major media initiative that year. This was the first (and only) press conference with an open accreditation of a large number of foreign and domestic journalists and where he was able to provide extended commentaries on various domestic and foreign policy issues of the day. ${ }^{11}$

In the analysis of written texts we collected policy programmes of major political forces: programme of the united democratic opposition Solidarnost, political manifesto of a liberal Pravoe Delo (Just Cause) party, the most recent programme of the Communist party, KPRF. We also included the widely publicised Nikita Mikhalkov's Manifest of the Enlightened Conservatism, which was positioned as the defence of statism and conservative values and adopted by factions within the

${ }^{10}$ Gennady Zyuganov's `The Politics of Majority is Course to Victory' report at the XIV convention of KPRF (24 September 2011); Sergey Mironov's speech at the VI party convention of Just Russia (SR) (24 September 2011), Mikhail Prokhorov's speech at the Pravoe Delo party convention (25 June 2011); Grigory Yavlinsky's speech at the XVI convention of Yabloko (10 September 2011). The speech of another parliamentary party leader, Vladimir Zhirinovsky at the XXIII convention of LDPR (13 September 2011) is omitted from the analysis because the authors could not place it on the general leftright dimension after reading it and because the rhetorical 'format' of the speech is different from other speeches. We also include an extended speech on economic and political development of Russia by finance minister Alexei Kudrin, made at the economic forum (18 February 2011).

11 The text was pre-processed by deleting all questions by journalists, all specific references to questions in the president's answers, all short answers and discussions, leaving only text that covers Medvedev's policy rhetoric. Additionally, we deleted sections of the text that can be attributed to Medvedev's duties as president, rather than his policy as such. 
conservative political elites. Additionally, we included Medvedev's Russia, Forward! - a programmatic article that exposes the president's views about political development and the role of the state in Russia. Finally, to estimate Putin's position, we selected one of seven policy articles published by him in the main newspapers in early 2012 prior to the election that most closely corresponds to the texts of other actors with the topics covered. We selected his 'Russia: the national question', in Nezavisimaya Gazeta on 23 January 2012, in which he underlines his views on the role of the state and the individual. ${ }^{12}$

We ran two separate estimations on both samples of documents using Wordfish. We preprocessed all the documents by converting all words into lower-case, removing numbers and white spaces and stemming words as appropriate using Russian dictionaries. Additionally, words that appear in fewer than three documents are deleted. Figure 1 presents Wordfish estimates with corresponding bootstrapped confidence intervals.

[Figure 1 about here]

Looking at Figure 1 we believe that it captures the alignment of top political figures to two distinct dimensions. The first captures relative placements of key politicians on the general left-right dimension that spans from left-wing Communist views to the pro-business liberal democratic agenda on the right. The second gauges differences on the crucial liberalism-statism dimension of Russian politics.

The placement of political figures in Figure 1 has good face validity and will be very intuitive to any informed observer of Russian politics. The leaders of the communist and socialist parties, Zyuganov and Mironov, respectively, are placed on the left of the scale, while Kudrin, Prokhorov and Yavlinsky who espouse more economically- and socially-liberal views are all placed on the right. Based on their political rhetoric Medvedev and Putin can be clearly differentiated on the general left-

\footnotetext{
${ }^{12}$ In order to ensure that we could compare on the liberal-statism dimension, we deleted economic and socio-economic sections from Solidarnost's ‘300 Steps for Freedom' and left only sections on the role of the state and civil liberties. Other texts do not have dedicated economic sections and just relate to economic policies in the context of their discussion of the role of the state. This makes the document matrix much more comparable.
} 
right dimension. In fact, while Putin is placed somewhat in the centre between socialist Mironov and liberal Kudrin, Medvedev is estimated to be to the right of all included actors. The second panel maps the liberalism dimension and equally supports the validity of the computerised text analysis methodology in the Russian context: liberal Solidarnost and Pravoe Delo manifestos are placed correctly on the one pole of the dimension. In contrast $K P R F$ and ideas vocalised by Nikita Mikhalkov advocate statist and socially-conservative views and are placed on the opposite pole. Crucially, Medvedev is placed closer to the liberal pole than Putin. Our results in Figure 1 indicate that the positions of Medvedev and Putin can be differentiated on core political dimensions. The PM can be generally characterised as leaning towards the left on the general left-right dimension and being more politically conservative. At the same time Medvedev tends to occupy the more liberal position on both dimensions. Thus, both leaders can be viewed as distinct political figures that appear to signal real alternatives to the political elite, and occupy distinct policy space.

\section{USING RHETORIC TO ANALYSE THE DISTRIBUTION OF POWER IN THE TANDEM}

In the remainder of the paper we assess the relative influence of Putin and Medvedev as viewed by regional elites. In order to differentiate the reaction of political elites to the policy signals of their leaders we require, firstly, a setting with more than one leader or a considerable uncertainty over the identity of prospective leader and, secondly, for leaders to have distinct policy positions. In the previous sections we evaluated these conditions. Given that in Russian setting regional elites are welltrained political animals, this allows us to harvest the 'wisdom of crowds' and to assess the elite perceptions on who would run for the election in 2012 well ahead of the official announcement. We believe that the causal mechanism is as follows: once the president and prime minister publicly signalled their policy preferences, the elites react. As described in the previous section both leaders have distinct policy positions. Once the latter publicly broadcast their policy preferences, the elites internalise the signal and this will be captured by the rhetoric of the regional elites. By observing their reactions to speeches made by the two leaders we can infer the extent of elite unity and uncertainty over the distribution of power, and also any perceived shifts in the distribution of power in the tandem. 


\section{Federal And Regional Parliamentary Addresses As Sources Of Data}

As the data sources for this part of the analysis we focused on the legally required annual policy addresses by the president and prime minister who address national parliament, and regional leaders who address regional legislatures. The annual parliamentary addresses by the president and prime minister are similar in form to the annual 'State of the Union' addresses of US presidents to Congress (Cohen 1995). In the Russian case, both heads of the executive give annual addresses. They are the most comprehensive documents in terms of their policy scope, most referenced in the media, and can be reasonably expected to reflect the policy positions of the leadership on several policy dimensions, rather than 'cheap talk'. Presidential addresses usually discuss current problems, review policy implementation and declare policy directions for the future (see e.g., Baturo \& Mikhaylov 2007). The president also lays out tasks for the government and formulates legislative agenda, reviews the implementation of tasks and fulfilment of legislative agenda throughout the year. All Russian presidents beginning with Yeltsin in 1994 annually addressed the federal parliament. However, a formal legislative address by the prime minister was introduced and delivered by Putin for the first time in 2009. ${ }^{13}$ The annual addresses of both leaders are documents with relatively little room for improvisation on the day. Both address the legislature, both report on developments during the preceding year and set goals for the following year, and both are of comparable length. For instance, Putin's 2010 speech (excluding questions and answers) contains 9,100 words; Medvedev's speech is 7,424 words. The presidential addresses had longer sections on foreign affairs than those of the PM, and in the analysis we omitted these sections. All questions and answers are also omitted.

While the President and PM's legislative addresses touch upon common topics, they also reveal differences in the emphasis on (and preference towards) certain policies, norms and values, similarly to other texts analysed in the section above. For example, in their 2009 addresses Medvedev mentioned 'democracy' eight times, while the PM did not mention it at all. Likewise, the former included 'modernisation' 20 times in his speech --- versus none in the PM's speech; 'freedom' or its deviates (like 'free') were encountered 13 times --- versus none, 'corruption' --- 11 times versus none in Putin's speeches. However, both mentioned 'stability', 'energy' (and its derivatives), 'citizens' (and

\footnotetext{
${ }^{13}$ Traditionally, government reports annually to parliament where it faces questions from MPs about the implementation of the tasks outlined in the president's address.
} 
'civic') an almost equal number of times. Although they rarely declared opposing policies --- a notable exception being the intervention in Libya -- they tended to emphasise or de-emphasise certain topics, thus signalling their personal policy preferences.

Our focus on regional governors is based on the assumption that collectively they should possess more information than outside experts or foreign diplomats. Furthermore, given the number of governors we can better leverage the 'wisdom of crowds'. Governors represent an important section of Russian elites and have always been crucial in delivering votes at federal elections, as well as regional parliamentary elections for the ruling party (Hale 2006; Reuter \& Robertson 2012; Solnick 2000). They have significant control over regional economies through administrative and regulatory powers (Hale 2003, p. 243). In fact, a weak electoral performance of the $U R$ in December 2011 can be partly attributed to the preceding replacement of powerful governors in several regions by Medvedev who replaced or re-appointed more than half of all governors during his time in office (Reuter \& Robertson 2012). The newly appointed governors were also considerably younger, with many from the same generation as the president. Unlike other areas that were shared between the president and PM, governor appointments, subject to confirmation by the regional legislature, remained largely the presidential prerogative. While in all likelihood Medvedev consulted his powerful peer in his appointments, ${ }^{14}$ he also had considerable freedom for manoeuvre in governor selection as well. Medvedev actively utilised his prerogative, often overriding the reservations of federal plenipotentiaries. While more often the president preferred to wait until current terms expired to replace the long-standing governors, many were forced to step down early.

Because the governors were still uncertain about the identity of the president who would reappoint them after 2012, they were in a unique position of being acutely sensitive to, and cumulatively much better informed, than outside observers about the distribution of power in the executive duopoly. Therefore, the leaders of sub-national units provided a perfect expert pool for empirical analysis of

\footnotetext{
${ }^{14}$ We know that at least during the president's first year in office, before the list of candidates was presented to President Medvedev, the head of presidential administration contacted Premier for confirmation. Many governors preferred addressing (and appealing to) both leaders: for instance, when threatened with dismissal, Dar'kin of Primor'e discussed it with both (Kostenko, Glinkin \& Nikol'sky 2009). Also, Medvedev himself as President Putin's chief of staff (2003-05) had earlier wielded serious influence over appointments and patronage.
} 
latent processes within Russian governing circles. While it is impossible to successfully run such an expert survey, we expect that unelected regional elites strategically signalled their preference for (or affiliation with) leaders of the Russian executive.

Hale (2006, pp. 211-216) argues that governors faced a serious co-ordination problem that prevented them from building a political party to challenge the federal centre, as many ambitious individuals saw themselves as leaders and the Kremlin was able to exploit or co-opt them. Over the course of Putin's presidency, governors lost the ability to influence politics at federal level; there are good reasons to expect that governors would have coordinated around any individual nominated by the Kremlin, whether Putin or Medvedev. Co-ordination by the centre can break, however, when there exists uncertainty over the effective or prospective incumbent leader, as evidenced by governor support for two competing federal parties in the 1999 elections (Golosov 2011, p. 626). However, all things being equal, because both federal leaders repeatedly underlined that they represented the same political force, in all likelihood governors would have gravitated towards whoever was perceived as more powerful and a prospective leader. Therefore, the analysis of their political rhetoric should reveal changes of perceived influence of the two political leaders. More specifically, by examining how governors react to the policy initiatives of the two federal leaders in their own political speeches over time, we can assess policy distances between individual members of the elite on the one hand, and Putin and Medvedev on the other. Over time, by observing collective shifts in elite political rhetoric that reflect that of either political leader, we can gauge the perceptions of influence of these two leaders on political elites.

In the analysis of the political rhetoric of regional elites we specifically focused on their annual addresses to regional parliaments. These are similar to the 'State of the State' addresses made by most US governors. Annual addresses by governors largely follow the same structure as those of federal leaders, while also covering corresponding regional issues. Speeches varied somewhat in length and scope (e.g. the parliamentary reports in Mordovia and Tula being the longest). Also, while annual governor addresses had become the norm in many regions, and some rivalled the federal president's annual address in scope, substance and even flair -- notably, the poslania of many presidents of ethnic republics, especially Shaimiev of Tatarstan, -- a considerable number of governors were reluctant to be held accountable by their legislatures. Legal requirements for annual addresses varied regionally, with some doing it on a voluntary basis and others not doing it at all. For example, after Boos became the 
governor of Kaliningrad in 2005 , the region stipulated that the governor's address to its parliament should be held only every five years. In Chechnya, after Ramsan Kadyrov had delivered his parliamentary address on 25 December 2007, the practice was suspended. In order to counter these tendencies, Medvedev signed into law mandatory annual reporting (ezhegodnye otchety) by governors to regional legislatures (Federal Law N 29-F3), which came into force on 29 March 2010.

In their own legislative speeches, many regional governors emulated the presidential addresses to Duma. The content, length and title of such speeches varied somewhat. Thus, they could be titled as the address (poslanie), report (otchet or doklad), policy speech (programnyi doklad), report on the social-economic development of the region or even speech (vystuplenie). Despite the differences in titles, one unifying theme was that they were all addressed to regional parliaments (sometimes in a joint session including the regional executive and the public), and covered diverse policy areas. Similarly to the federal addresses to Duma, these speeches accounted for work of the executive branch during a certain period in the past and set goals for the future. Finally, these addresses were held over regular intervals of time (usually annually), sometimes to coincide with the annual presidential address to Duma.

In our estimations, we include Putin's legislative addresses in 2009, 2010 and 2011, as well as his policy programme speech from $2008^{15}$ and Medvedev's addresses in 2008, 2009, 2010 and 2011. Also, in presidential and premier texts we delete sections that cover foreign affairs to make them more comparable with governor speeches in terms of the topics covered. We collected the annual addresses of governors to regional legislatures covering the period from 5 November 2008 through to 1 August 2012: a total of 233 sub-national legislative addresses (a full description of each speech is available from the supplementary materials). This number is very close to a complete population of official governors' legislative addresses in this period. We estimate that a dozen speeches made in this period are either not available in public domain, not available at the time of writing, or were available in video format only. Due to the low number of omitted texts the standard approaches dealing with data missingness were not necessary. Regarding 'missing' observations for governors who made no

\footnotetext{
${ }^{15}$ Putin's last presidential address was held in April 2007, rendering it rather distant for the purposes of comparison with speeches made in late 2008 and in 2009. On 8 February 2008 President Putin delivered 'On Strategy of Russia to 2020' at the State Council meeting that Kolesnikov (2008) described as comparable to a regular legislative address in format and scope, thus we use it for 2008.
} 
addresses at all, we treat these political actors as fundamentally uncertain who could not make their preference known about either political leader. The sample is largely representative of the wider population of governors in general relating to their appointment history, backgrounds, and career trajectories and includes regions across the whole country, representing areas of varied economic performance and varied dependence on federal fiscal transfers.

We analysed texts in four panels, each comprising the period between the annual presidential address in November of one year and the following November, so that all governor speeches are made after the respective speeches of the president, thus ameliorating possible `agenda shift' (e.g., Proksch \& Slapin 2009). Figure 2 explains the selection of reference and virgin texts schematically. Each panel includes the PM and president's speeches which precede those of governors. The 2011 and 2012 panels, even though they equally include governor speeches made after the president's speech, are slightly shorter than the 2009 and 2010 panels. Thus, the 2011 panel covers the period between 30 November 2010 and 24 September 2011 (the date when Putin was nominated and therefore when the uncertainty over nomination was over) and the last, 2012, panel extends from Medvedev's last speech in December 2011 to 1 August 2012 -- to the date to which we extended coverage.

[Figure 2 about here]

\section{Assessing The Distribution Of Power From Governors' Positions Over Time}

We assume that the speeches made by regional governors lie on the underlying dimension between the two poles of Russian political duopoly -- Premier Putin and President Medvedev. Governor speeches then reflect their preferences of being either pro Putin or pro Medvedev. Our interpretation from reading the speeches of regional chief executives is that to a large extent they either emphasise the themes from the president or PM's address, or try to mention the buzzwords from both addresses equally. We can therefore use governors' speeches as an indicator for how much a speaker signals support for one of the members of the political duopoly. Given the discussion above, in spatial terms we take relative closeness to either member of the dual executive to indicate governor's preference.

As discussed previously, this part of our analysis is conducted using Wordscore (Laver, 
Benoit \& Garry 2003). We set the scores of our reference texts at -1 for Medvedev and at +1 for Putin. Figure 3 shows estimated positions for all governors in our sample. Plots include the centre line at zero designating equidistance between Medvedev and Putin, and the line corresponding to the mean governor position. From the plot we can see that the mean is very close to the centre in 2009 compared to 2010 or 2011 , and especially 2012 . This would indicate that governors were initially more uncertain about the distribution of power, or that they equally favoured the PM and president. From late 2009 the centre of gravity seems to have shifted towards Medvedev. Indeed, throughout 2010 Medvedev was very assertive and his Russia, Forward! policy paper, as well as the November legislative address that emphasised the liberal modernisation programme, had a significant impact on political discourse.

[Figure 3 about here]

However, results for 2011 suggest that from December 2010 governors collectively shifted towards Putin. Prior to the 30 November 2010 presidential address many observers were led to believe that Medvedev would publicly challenge the party in power or declare his political intentions, but the president failed to deliver any significant criticism of the United Russia in his speech. ${ }^{16}$

In a slightly different visualisation of raw wordscores we computed averages for each time period. The movement of regional leaders towards Putin is even more clearly visible when presenting the data annually. Figure 4 plots raw wordscores over four time panels in our study. The figure also includes the mean governor position and 95 per cent confidence interval around the mean. Average position and corresponding uncertainty can be thought of as capturing a general centre of gravity of regional leaders' rhetorical positions for each time period. Figure 4 highlights relatively stable positions in 2009 and 2010, with movement to Putin from 2011 that continued in 2012.

[Figure 4 about here]

\footnotetext{
${ }^{16}$ For example, one week before the speech Medvedev publicly criticised the existing Russian political regime. See Medvedev, 23 November 2010, 'Nasha demokratiya nesovershenna, my eto prekrasno ponimaem. No my idem vpered.' Available at http://www.kremlin.ru/news/9599, accessed 20 April 2012.
} 
From Figures 3 and 4 it is difficult to assess the causes of the movements in the centre of gravity in governor positions. However, we believe that this reflects governor reactions to policy signals from their leaders. It may also reflect the uncertainty over which of the members of the governing tandem would run in the 2012 election. While we observe only the reaction of governors, we cannot observe the signals that both leaders send to the elites.

In order to validate our results, we compared our monthly scores with a monthly external expert survey of perceived political influence. ${ }^{17}$ Figure 5 plots the monthly difference in perceived political influence of Putin over Medvedev. As can be seen, the experts believe that in the time period under investigation, Putin is more influential most of the time. Overall, Putin's influence is at 9.42 (standard deviation of 0.19) and Medvedev's at $9.15(0.24)$ prior to 24 September 2011. On average, the difference in influence is $0.28(0.27)$ in the range between -0.19 and 1.14 in this period.

[Figure 5 about here]

In general, similarly to the Wordscore results, experts believe that the president's influence over policy was closely matched to that of the prime minister in 2009 and up to the end of 2010 . Experts also thought that Medvedev exceeded Putin's score only twice -- in September 2009 and June 2010, and they had an equal rank in February 2009. Indeed, in September 2009 Medvedev's perceived influence overcame that of Putin's for the first time following a series of highly-publicised statements by the president, including his appearances at the Yaroslavl' international security conference, the Valdai expert club and the publication of the Russia, Forward! article, in which he clearly differentiated himself from his prime minister. Likewise, the difference in perceived influence crosses the zero-line for the second time in June 2010 following Medvedev's speeches at the St Petersburg economic and G8 forums and his declaration of willingness to run for a second term.

\footnotetext{
${ }^{17}$ A monthly expert survey of the top 100 influential politicians in Russia whereby a number of experts are asked to answer the following questions anonymously: 'How do you rank, on a scale between 1 and 10, the influence of the following Russian politicians in the presidential administration, government, federal legislature?' See, for instance, Nezavisimaya Gazeta (2011) `100 Leading Politicians of Russia in November', 30 November, p. 9. The average scores reported. Results and the methodology can be accessed from the paper's archive at www.ng.ru, from May 2007.
} 
The president's perceived influence was regained again when he won the upper hand in the confrontation with the previously all-powerful mayor of Moscow, Luzhkov, and dismissed him in September $2010 .^{18}$ Following the appointment of Putin's loyalist Sobyanin as the new mayor of Moscow and until October 2010, the president's perceived influence took a downward trend. Similarly, the distance between the positions of the governors and the president increased from mid-2010.

It appears that governors and experts alike can pick up on a similar trend over time, which validates the usage of rhetoric to gauge the distribution of power. The results of the expert survey provide external validation to the results from our quantitative analysis of governor speeches. This supports our earlier observation that the governors appear to drift towards Putin from late 2010, compared to their earlier more centrist or even pro-Medvedev position. As can be seen from Figure 5, the two events in 2011 that signalled to experts that Medvedev's presidency was over were his highly publicised press-conference on 18 May 2011 in which he failed to declare his candidacy and the nomination of Putin for presidency on 24 September 2011. At the point of both events the difference in influence dramatically increased in Putin's favour. At the same time, the majority of governors purged their political rhetoric from the themes encountered in president's speeches during 2011 and especially in 2012. This demonstrates the change in governors' perception of power at the federal centre and that Medvedev's term in office characterised by liberal rhetoric was coming to an end.

\section{DISCUSSION AND CONCLUSIONS}

In this paper we showed how elite politics in Russia could be effectively examined by treating text as data. In simple terms, kremlinology can be improved upon by introducing the techniques developed in other contexts of political science. The results of our study support the assumptions often made in qualitative studies: political elites are indeed predominantly concerned about power and will

\footnotetext{
${ }^{18}$ See TVRain, (2011) 'Elena Baturina Asserted Real Reasons for Luzhkov's Dismissal', 16 December, available via http://tvrain.ru/teleshow/interview/, accessed 23 April 2012. Following this dismissal, the interlocutors of the influential Nezavisimaya Gazeta daily believed that the president and prime minister could not agree on the candidacy of the new mayor, and that the identity of the eventual appointee therefore would reveal whether Medvedev was ascendant or not (Bilevskaya \& Rodin 2010).
} 
support whoever appears to be more dominant. Overall, we believe that President Medvedev was neither a figurehead president nor a fully-fledged successor, and that the key elite members were uncertain about the 2012 nomination. Russian political elites follow cues from their leaders and are willing to shift policy positions when required. In that they are not different from the elites in the late Soviet Union era that, emulating Gorbachev, adopted more liberal and democratic rhetoric. We can also infer that political elites are likely to rally around whoever is perceived as more influential in the federal centre, regardless of whether they espouse more conservative or liberal policies.

Many observers of Russian politics regard Medvedev's presidency as a failure (Shevtsova \& Kramer 2012). Arguably, however, because the office of the president is so focal, Medvedev's liberal rhetoric, prominently broadcast to the elites and public at large, contributed to a wider acceptance of democratic values. Another implication is that institutions do matter and even managed succession is dangerous: even though Putin remained the de facto leader during his successor's term, and the latter was unable to engage in his own 'authority building' (Breslauer 1982), Medvedev ensured that his patron returned to office in a much weaker regime. Putin's nomination in all likelihood contributed to the series of unprecedented protests in late 2011-2012. Indeed, as early as March 2011, as the results of focus group research have revealed, even though the majority considered Medvedev rather weak, bringing Putin back was expected to provoke a negative reaction among social groups expecting economic and political changes (Belanovsky \& Dmitriev 2011, pp. 10-19). The subsequent replacement of officials appointed by Medvedev, dismissal of journalists, new draconian legislation restricting civil liberties after Putin's return only underline that Medvedev was less of a figurehead than regarded by many.

The validity of our argument crucially hinges on the premise that public statements reveal elite preferences. However, in the absence of other information, or perhaps in addition to it, we believe that we can gain insights into the murky world of non-institutionalised polities from political rhetoric. The duality of executive power in Russia represents an interesting opportunity to differentiate between the effect of a leader and leadership position (Ahlquist \& Levi 2011, p. 19). As discussed earlier, many regimes around the world experience the dual executive, whether genuine or not. These conditions create an excellent setting in which to observe elite behaviour under uncertainty.

The analysis of intra-regime politics remains understudied in quantitative studies. Scholars interested in studying elite coordination and the emergence of regime splits and defections can employ 
methods similar to those used in studies of party competition in democracies. There is a recent surge of theoretical literature that explains elite coordination between rulers and their coalitions in authoritarian regimes (e.g., Bueno de Mesquita, Smith, Siverson \& Morrow 2003; Magaloni 2008). Elite splits can occur when factions emerge that advocate for policy change (Przeworski 1991, pp. 55-57) when there is disagreement over succession (Hale 2005), and during economic crises (Reuter \& Gandhi 2011). Unlike empirical studies that examine the electoral process in order to understand elite management (e.g., Reuter \& Robertson 2012), we rely on the analysis of political rhetoric and explain how the study of policy preferences can improve our understanding of elite responses to the conflicting policy signals of leaders and how splits can potentially emerge. In general, we demonstrate how scholars can study latent political processes using text as data in difficult settings such as the Russian political regime. 


\section{REFERENCES}

Ahlquist, J. \& Levi M. (2011) 'Leadership: What It Means, What It Does, and What We Want to Know About It', Annual Review of Political Science, 14, pp. 1-24.

Bailey, M., Sigelman L. \& Wilcox C. (2003) 'Presidential Persuasion on Social Issues: A Two-Way Street?' Political Research Quarterly, 56, 1, pp. 49-58.

Baturo, A. (forthcoming) Democracy, Dictatorship, and Term Limits (Ann Arbor, MI, Michigan University Press).

Baturo, A. \& Mikhaylov S. (2007) 'I Love You, You Pay My Rent: the Game of Belarusian-Russian Integration', in Dusseault D. \& Sakwa R. (eds) The CIS: Form or Substance (Helsinki, Helsinki University Press), pp. 98-130.

Belanovsky, S. and Dmitriev M. (2011) Politicheskij krizis v Rossii i vozmozhnye mehanizmy ego razvitiya (Moscow, Tsentr Strategicheskih Razrabotok).

Benoit, K. and P. Nulty. (2013). “Classification Methods for Scaling Latent Political Traits.” Paper prepared for presentation at the Annual Meeting of the Midwest Political Science Association, April 11-14, 2013, Chicago.

Bilevskaya, E. \& Rodin I. (2010) `One Chair -- Many Candidates’, Nezavisimaya Gazeta, 30 September.

Brace, P. \& Hinckley B. (1992) Follow the Leader (New York, Basic Books).

Breslauer, G. (1982) Khrushchev and Brezhnev as Leaders: Building Authority in Soviet Politics (New York, Harper Collins). 
Bueno de Mesquita, B., Smith A., Siverson R. \& Morrow J. (2003) The Logic of Political Survival (Cambridge, Mass., MIT Press).

Canes-Wrone, B. (2001) 'The President's Legislative Influence from Public Appeal', American Journal of Political Science, 45, pp. 313-29.

Cheibub, J., Gandhi, J. \& Vreeland, J. (2010) 'Democracy and Dictatorship Revisited', Public Choice, 143, 2-1, pp. 67-101.

Chehabi, H. \& Linz J. (1998) Sultanistic Regimes (Baltimore, Johns Hopkins University Press).

Cohen, J. (1995) 'Presidential Rhetoric and the Public Agenda', American Journal of Political Science, 39, 1, pp. 87-107.

Duchatel, M. \& Godement F. (2009) 'China’s Politics under Hu Jintao', Journal of Current Chinese Affairs, 3, pp. 3-11.

Edwards, G. (1996) 'Presidential Rhetoric: What Difference Does it Make?' in Medhurst M. (ed) Beyond the Rhetorical Presidency (College Station, Texas A\&M University Press), pp. 199-217.

Edwards, G. (2003) On Deaf Ears: The Limits of the Bully Pulpit (New Haven, CT, Yale University Press).

Gandhi, J. (2008) Political Institutions under Dictatorship (Cambridge; New York, Cambridge University Press).

Gessen, M. (2012) The Man Without a Face: the Unlikely Rise of Vladimir Putin (London, Granta).

Gibbon, E. (1998 [1776-88]) The Decline and Fall of the Roman Empire (London, Wordsworth Editions Limited). 
Golosov, G. (2011) 'Regional Roots of Electoral Authoritarianism in Russia', Europe- Asia Studies, 63, 4, pp. 623-639.

Grimmer, Justin and Brandon Stewart. "Text as Data: The Promise and Pitfalls of Automatic Content Analysis Methods for Political Texts.” Political Analysis forthcoming.

Hale, H. (2003) 'Explaining Machine Politics in Russia’s Regions: Economy, Ethnicity, and Legacy', Post-Soviet Affairs, 19, 3, pp. 228-263.

Hale, H. (2005) 'Regime Cycles: Democracy, Autocracy, and Revolution in Post-Soviet Eurasia', World Politics, 58, 1, pp. 133-165.

Hale, H. (2006) Why Not Parties in Russia? Democracy, Federalism, and the State (New York, Cambridge University Press).

Hale, H. (2010) 'Russia's Political Parties and their Substitutes', in White S. (ed) Developments in Russian Politics 7 (New York, Palgrave Macmillan), pp. 81-98.

Jégo, M. (2011) 'La `realpolitik post-impériale’ de la diplomatie Russe', Le Monde, 30 March.

Kolesnikov, A. (2008) Razdvoenie VVP: Kak Putin Medvedeva Vybral (Moscow, Biblioteka Kommersant).

Kostenko, N., Glinkin M. \& Nikol'sky A. (2009) 'Vlast' nadvoe skazala', Vedomosti, 7 May.

Kostenko, N., Taratuta Y. \& Glinkin M. (2011) `Snova Putin’, Vedomosti, 26 September.

Laver, M. \& Benoit K. (2002) 'Locating TDs in Policy Spaces: Wordscoring Dail Speeches', Irish Political Studies, 17, 1, pp. 59-73. 
Laver, M., Benoit K. \& Garry J. (2003) `Extracting Policy Positions from Political Texts Using Words as Data', American Political Science Review, 97, 311-331.

Lentz, H. (1994) Heads of States and Governments: a Worldwide Encyclopedia of Over 2,300 Leaders, 1945 through 1992 (London: McFarland and Co).

Lewis, P. (1978) 'Salazar's Ministerial Elite, 1932-1968', Journal of Politics, 40, pp. 622-47.

Lowe, W. (2008) 'Understanding Wordscores', Political Analysis, 16, 4, pp. 356-371.

Lowe, W. (2011) 'austin: Do things with words', R package version 0.1', available via https://r-forge.rproject.org/projects/austin/, accessed August 2012.

Lowenthal, R. (1974) 'On 'Established' Communist Party Regimes', Studies in Comparative Communism, 7, 4, pp. 335-58.

Lukic, R. (2005) 'From the Federal Republic of Yugoslvia to the Union of Serbia and Montenegro', in Ramet S. \& Pavlakovic V. (eds) Serbia Since 1989 Politics and Society under Milošević and After (Seattle, University of Washington Press), pp. 55-94.

Magaloni, B. (2008) 'Credible Power-Sharing and the Longevity of Authoritarian Rule', Comparative Political Studies 41, 4-5, pp. 715-41.

Medvedev, D. (2009) 'Russia, Forward!' available via http://kremlin.ru/news/5413, accessed 17 March, 2011.

Neustadt, R. (1990) Presidential Power and the Modern Presidents (New York: Free Press).

Northouse, P. (2009) Leadership: Theory and Practice, 5th ed. (Sage Publications, Inc). 
Orlov, D. (2011) 'Strategiya-2036', Nezavisimaya gazeta, 26 September.

Proksch, S.-O. \& Slapin J. (2009) 'How to Avoid Pitfalls in Statistical Analysis of Political Texts: The Case of Germany', German Politics, 18, 3, pp. 323-344.

Przeworski, A. (1991) Democracy and the Market (New York, Cambridge University Press).

Ragsdale, L. (1987) 'Presidential Speechmaking and the Public Audience: Individual Presidents and Group Attitudes', Journal of Politics, 49, pp. 704-36.

Rahr, A. (2008) Russland gibt Gas (Die Ruckkehr einer Weltmacht) (Munich, Carl Hanser Verlag).

Remington, T. \& Reuter, Ora J. (2009) 'Dominant Party Regimes and the Commitment Problem: the Case of United Russia', Comparative Political Studies, 42, pp. 501-526.

Reuter, Ora J. \& Gandhi, J. (2011) 'Economic Performance and Elite Defection from Hegemonic Parties', British Journal of Political Science, 41, pp. 83-110.

Reuter, Ora J. \& Robertson, G. (2012) 'Sub-national Appointments in Authoritarian Regimes: Evidence from Russian Gubernatorial Appointments', Journal of Politics, 74, 4, pp. 1023-1037.

Riker, W. (1986) The Art of Political Manipulation (New Haven: Yale University Press).

Ryavec, K. (1982) 'The Soviet Leadership Succession: Change and Uncertainty', Polity, 15, 1, pp. $103-122$.

Sakwa, R. (2010) The Crisis of Russian Democracy: The Dual State, Factionalism and the Medvedev Succession (Cambridge: Cambridge University Press). 
Samarina, A. (2011) 'Vizit Baidena kak Signal Elitam', Nezavisimaya gazeta, 4 March.

Shevtsova, L. \& Kramer D. (2012) 'Medvedev the Phony’, Foreign Policy, 7 May online edition, 2012, available via http://www.foreignpolicy.com/articles/2012/05/07/medvedev the phony, accessed 1 June 2012.

Slapin, J. \& Proksch, S.-O. (2008) `A Scaling Model for Estimating Time-Series Party Positions from Texts', American Journal of Political Science, 52, 3, pp. 705-722.

Solnick, S. (2000) 'Is the Center Too Weak or Too Strong in the Russian Federation', in Sperling V. (ed) Building the Russian State: Institutional Crisis and the Quest for Democratic Governance (Boulder, Colorado, Westview Press).

Surowiecki, J. 2004. The Wisdom of Crowds. New York: W.W. Norton \& Company, Inc.

Tulis, J. (1987) The Rhetorical Presidency (Princeton, NJ, Princeton University Press).

Urnov, M. (2011) 'Modernization in Russia: Clash of Concepts', Moscow, Higher School of Economics, Typescript.

Walter, K. (1993) The Regime of Anastasio Somoza, 1936-1956 (Chapel Hill, N.C., and London, University of North Carolina Press).

Weldon, J. (2007) 'The Political Sources of Presidencialismo in Mexico', in Mainwaring, S. \& Shugart, M. (eds) Presidentialism and Democracy in Latin America (Cambridge; New York, Cambridge University Press), pp. 225-258.

Whitfold, A. \& Yates J. (2003) `Policy Signals and Executive Governance: Presidential Rhetoric in the War on Drugs', Journal of Politics, 65, 4, pp. 995-1012. 
Wood, D., Owen C., \& Durham B. (2005) 'Presidential Rhetoric and the Economy', Journal of Politics, 67, 3, pp. 627-645. 
General Left-Right

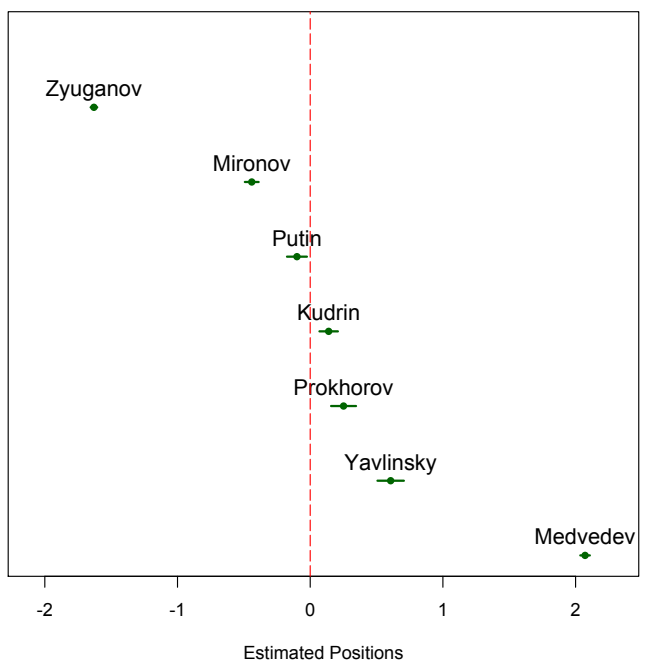

Liberalism-Statism

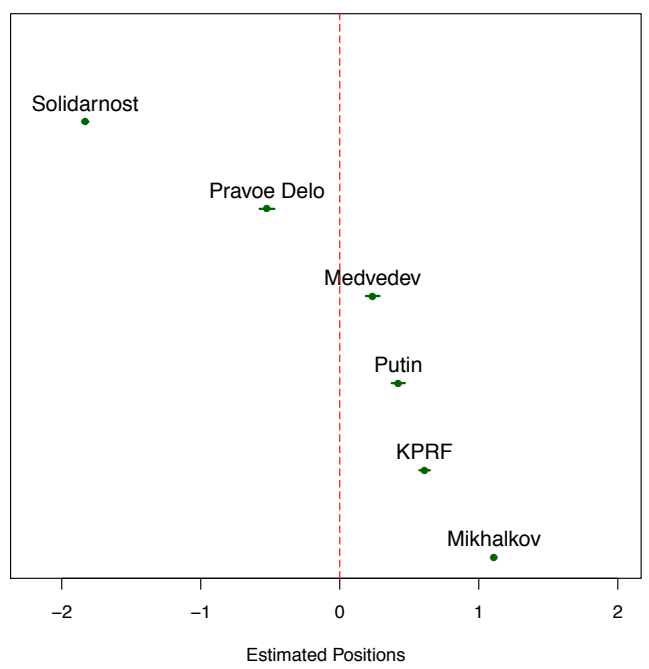

Figure 1: Estimates of Policy Positions on General Left-Right and Liberalism-Statism Dimensions.

Note: Two separate scaling estimations using the Wordfish algorithm. The left panel presents results of scaling political speeches made at party conventions (or equivalent) in 2011, mapping on the general left-right dimension. The right panel shows the scaling results of written party manifestos or political programmes, and mapping on the liberalism-statism dimension. On the vertical axes texts are arranged in the order from left to right. Ideal point estimates and bootstrapped $95 \%$ confidence intervals. 


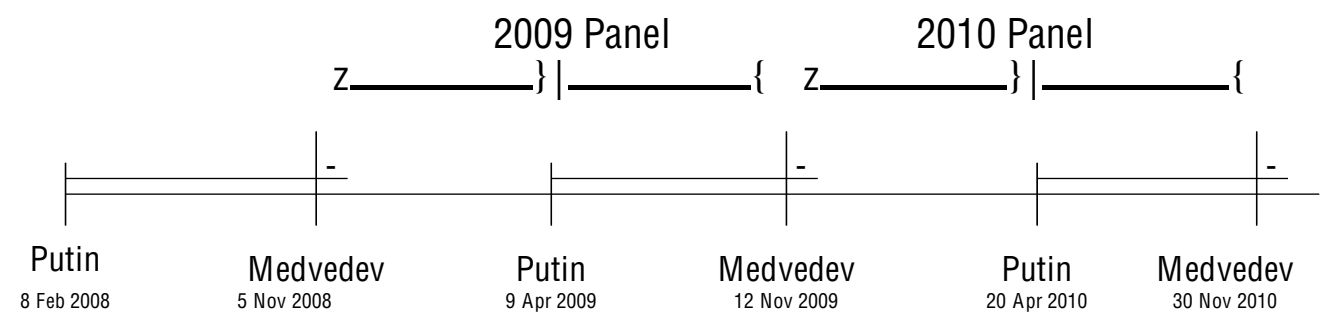

Figure 2: Selection of Reference and Virgin Texts for Wordscoring Panel.

Note: Each panel includes all governor speeches made between the president's annual address in the previous year and the current year's presidential address. Presidential and PM addresses from the previous year are used as reference texts for the current year. 2009 and 2010 panels are selected for illustrative purposes. 

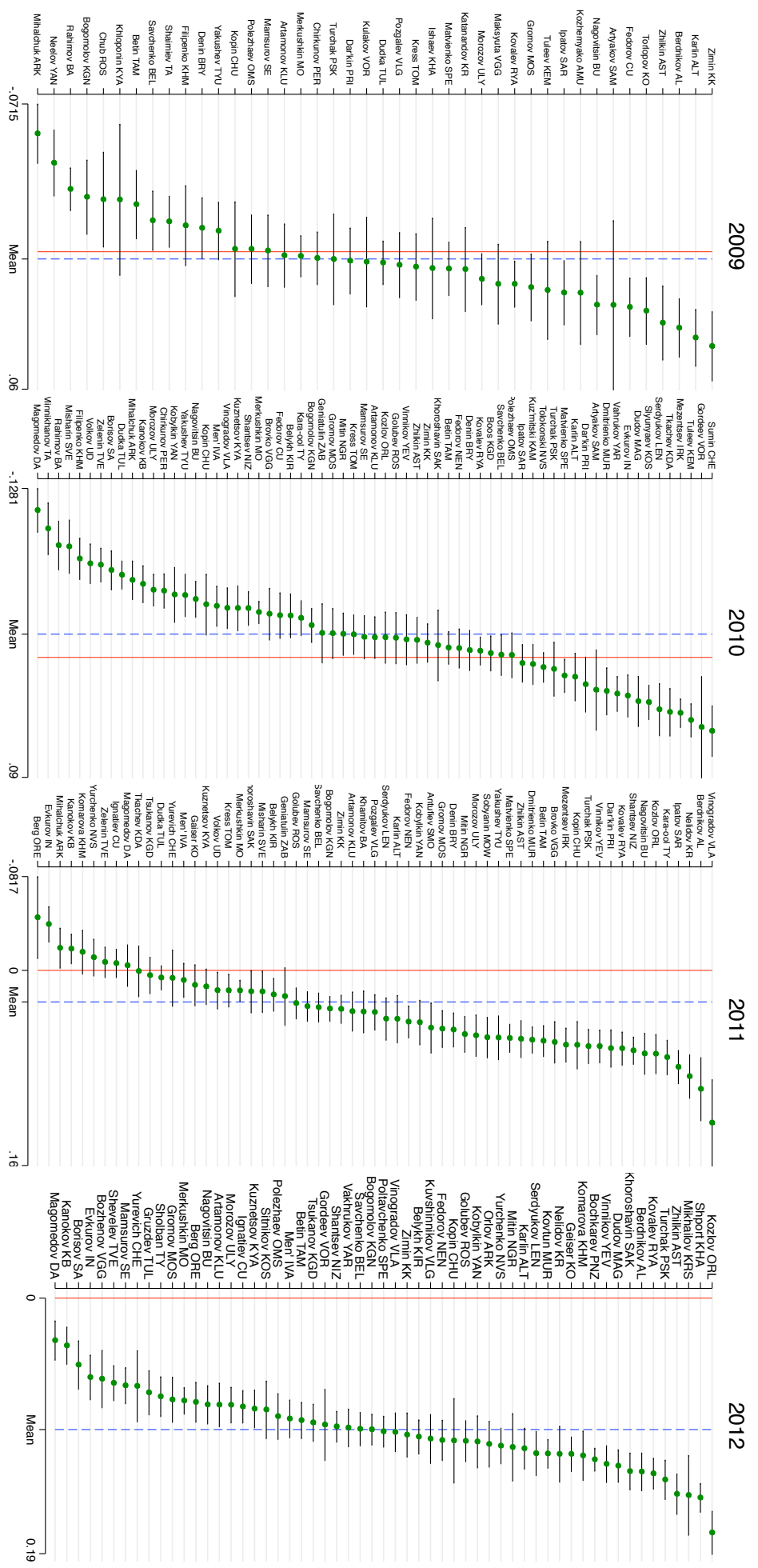

Figure 3: Affinity of Sub-national Elites to Federal Leaders, from Political Rhetoric, 2009-2012.

Note: Estimated positions and 95\% confidence intervals. Medvedev's position is anchored on the left and Putin on the right. 


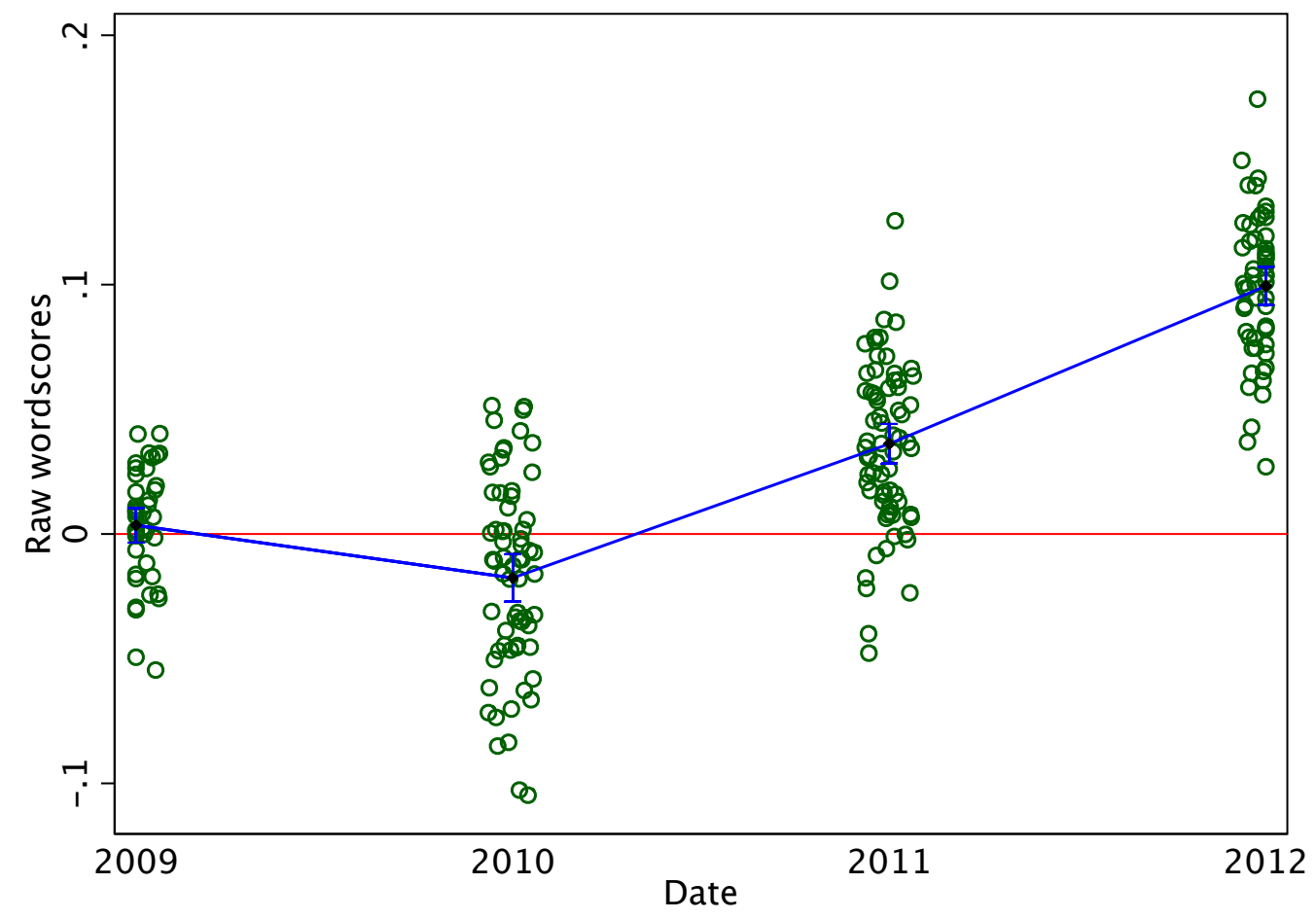

Figure 4: Average Policy Distances of Sub-national Elites to Federal Leaders, from Political Rhetoric, 2009-2012.

Note: With the average value for each year and $95 \%$ confidence interval for averages. The plot captures general centre of gravity of regional leaders across four years. 


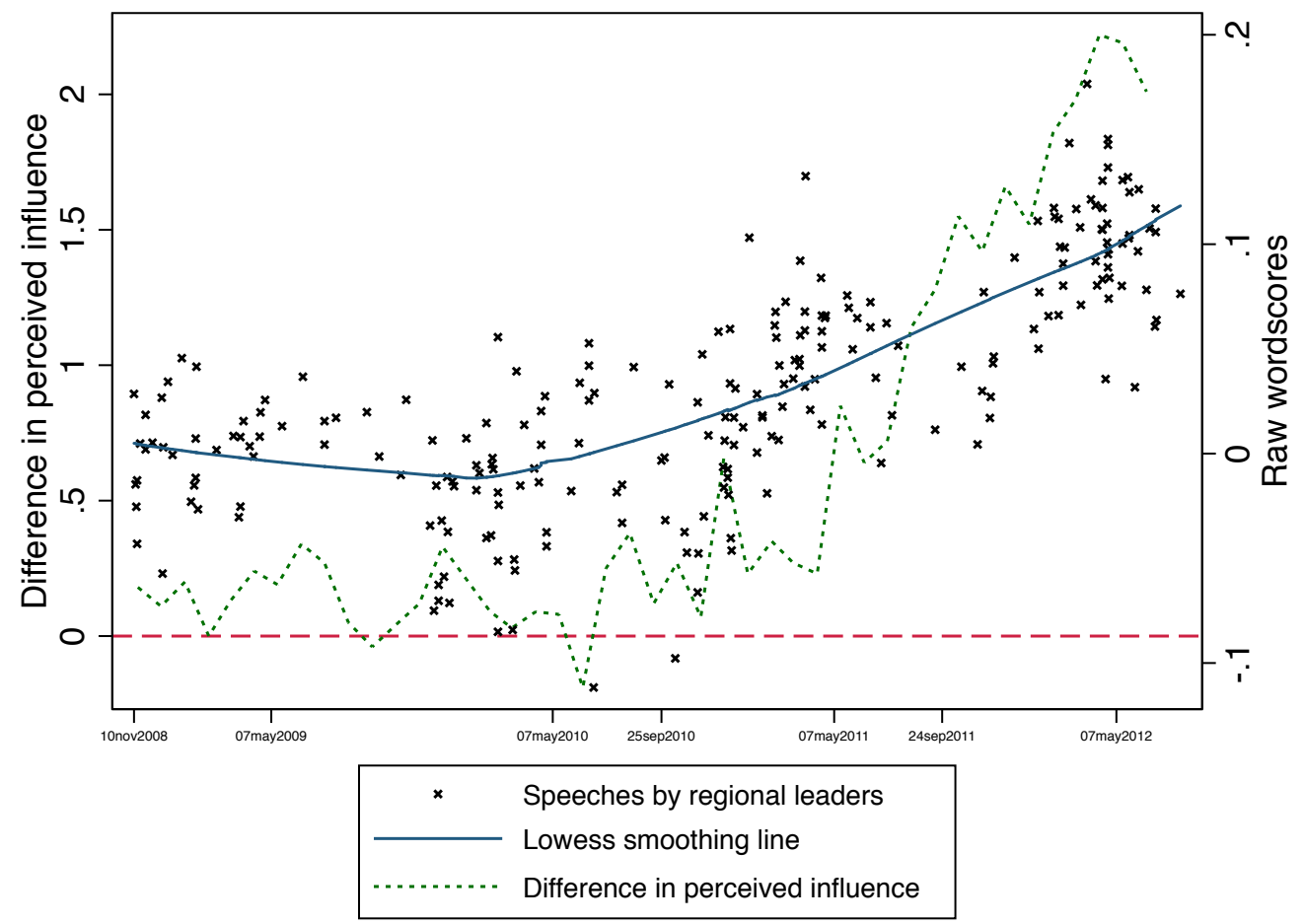

Figure 5: The Perceived Political Influence and Scores from Governors' Speeches, 2008-2012.

Note: Perceived political influence is taken from monthly expert surveys, Nezavisimaya Gazeta-APEK. The dashed line is the difference in perceived expert survey scores between Putin and Medvedev (left hand-side axis, higher scores indicate more influence by Putin versus Medvedev). Scatter plot maps legislative addresses made by regional leaders (right hand-side axis, higher scores indicate positions closer to Putin), with the local regression line fitted through. 